\title{
Stage IV Lip and Oral Cavity Squamous Cell Carcinoma AJCC v6 and v7
}

National Cancer Institute

\section{Source}

National Cancer Institute. Stage IV Lip and Oral Cavity Squamous Cell Carcinoma A/CC v6 and v7. NCI Thesaurus. Code C115060.

Stage IV includes: IVA (T4a, N0, M0); (T4a, N1, M0); (T1, N2, M0); (T2, N2, M0); (T3, N2, M0); (T4a, N2, M0);. IVB (Any T, N3, M0); (T4b, Any N, M0); IVC (Any T, Any N, M1). T4a (lip): T umor invades throug cortical bone, inferior alveolar nerve, floor of mouth, or skin of face, i.e., chin or nose. T4a (oral cavity): Tumor invades adjacent structures (e.g., through cortical bone, into deep [extrinsic] muscles of tongue, maxillary sinus, skin of face). T4b: Tumor invades masticator space, pterygoid plates, or skull base and/or encases internal carotid artery. N2: Metastasis in a single ipsilateral lymph node, more than $3 \mathrm{~cm}$ but not more than $6 \mathrm{~cm}$ in greatest dimension; or in multiple ipsilateral lymph nodes, none more than $6 \mathrm{~cm}$ in greatest dimension; or in bilateral or contralateral lymph nodes, none more than $6 \mathrm{~cm}$ in greatest dimension. N2a: Metastasis in a sing le ipsilateral lymph node more than $3 \mathrm{~cm}$ but not more than $6 \mathrm{~cm}$ in dimension. N2b: Metastasis in multiple ipsilateral lymph nodes, none more than $6 \mathrm{~cm}$ in greatest dimension. N2c: Metastasis in bilateral or contralateral lymph nodes, none more than $6 \mathrm{~cm}$ in greatest dimension. N3: Metastasis in a lymph node more than $6 \mathrm{~cm}$ in greatest dimension. M1: Distant metastasis. (AJCC 6th and 7th eds.) 